\title{
Burial environment and geoheritage value of dinosaur fossils of the Middle Jurassic- Puan, Yunyang, Chongqing Municipality
}

\author{
${ }^{1}$ College of Earth Science, Chengdu University of Technology, Chengdu, 610059, China \\ ${ }^{2}$ Institute of Sedimentary Geology, Chengdu University of Technology, Chengdu, 610059, China; *Corresponding author, E-mail: yangwg1018@ \\ gmail.com \\ ${ }^{3}$ Chongqing Laboratory of Geoheritage Protection and Research, No. 208 Hydrogeological and Engineering Geological Team, Chongqing \\ Bureau of Geological and Mineral Resource Exploration and Development, Chongqing, 40070, China \\ ${ }^{4}$ Chongqing Institute of Geological Survey, Chongqing, 401122, China
}

(Received: July 13, 2020; Revised accepted: December 25, 2020)

https://doi.org/10.18814/epiiugs/2020/020094

\begin{abstract}
A Jurassic site in the Puan area (Yunyang County, Chongqing Municipality) with paleontological heritage of dinosaur fossils is regarded as having high scientific and touristic value. The paleontological field's geoheritage value was used to approve the establishment of a national geopark in 2020, which may promote socioeconomic development for the local population. The study and protection of these dinosaur fossils is still a necessity for establishing a geopark that will strengthen the protection and development of this area. The fossils in this region were recovered from the Middle Jurassic Xintiangou Formation and Lower Shaximiao Formation. Herein, we describe the background of the fossil burial in conjunction with sedimentology, and then we discuss the scientific and socioeconomic significance of the dinosaur fossils' geoheritage value.
\end{abstract}

\section{Introduction}

Geoheritage consists of nonrenewable resources (Fuertes-Gutiérrez et al., 2016), that document the long geological history of the evolution of the earth. Among the many kinds of geoheritage, dinosaur fossils always attract people's interest. For a long time, the Sichuan Basin has witnessed numerous discoveries of dinosaur tracksites from extensive outcrops of Triassic, Jurassic, and Cretaceous strata (e.g., Xing et al., 2013; Xing et al., 2014; Xing et al., 2016; Xing et al., 2018) and dinosaur bones from outcrops of Jurassic strata (e.g., Luo and Wang, 1999; Barrett et al., 2005). Chongqing Municipality, which is located in the eastern Sichuan Basin, and known for its rich dinosaur fossils (including dinosaur bones and dinosaur tracksites), is hailed as a city built on the backs of the dinosaurs. To date, dinosaur fossils (including dinosaur bones and dinosaur tracksites) have been discovered in a total of 24 districts in Chongqing Municipality (based on communication with the staff of the No. 208 Hydrogeological and Engineering Geological Team).
The paleontological geological heritage of dinosaur fossils has excellent scientific and socioeconomic value, which can not only improve our understanding of the earth's evolutionary history, but also brings economic effects to the local area by promoting geological tourism, and at the same time enhancing regional's visibility (such as Zigong Sichuan, Lufeng Yunnan, and Zhucheng Shandong, etc., which are famous for their dinosaur fossils). At present, China is carrying out comprehensive poverty alleviation work. Yunyang County lifted itself out of poverty in 2018, and is now in the stage of consolidating the achievements of poverty alleviation and realizing rural revitalization.

The discovery of the Puan dinosaur fossils will undoubtedly provide a new development resource of geological tourism to this area. The government has promised to invest 4 billion yuan in the construction of the Yunyang dinosaur park. Thus, we can expect that the dinosaur geopark will play an important role in promoting the local geological tourism economy.

The organism is a critically important component of the earth system and dinosaurs were once rulers of the earth, the causes of their massive death and extinction are worth exploring. In the origin and evolution of dinosaurs, there was a close association between the environments (Benson, 2018). The evolutionary history of the earth recorded by the geological remains of dinosaurs, which are of practical significance in the prediction of the future evolution of the biosphere (Davies et al., 2020) and mitigation the current biodiversity extinction event (Novacek and Cleland, 2001).

\section{Geological Setting of Study Area}

The paleontological geological heritage of dinosaur fossils is located in the region of Puan Township, Yunyang County, Chongqing Municipality, China (Fig. 1). The geology of Yunyang County has simple structural features, it is composed of folds and a defined a NE-SW trending area of excellently exposed Triassic and Jurassic continental deposits, with no crystal basement found (Wang et al., 2010). In this region, the 


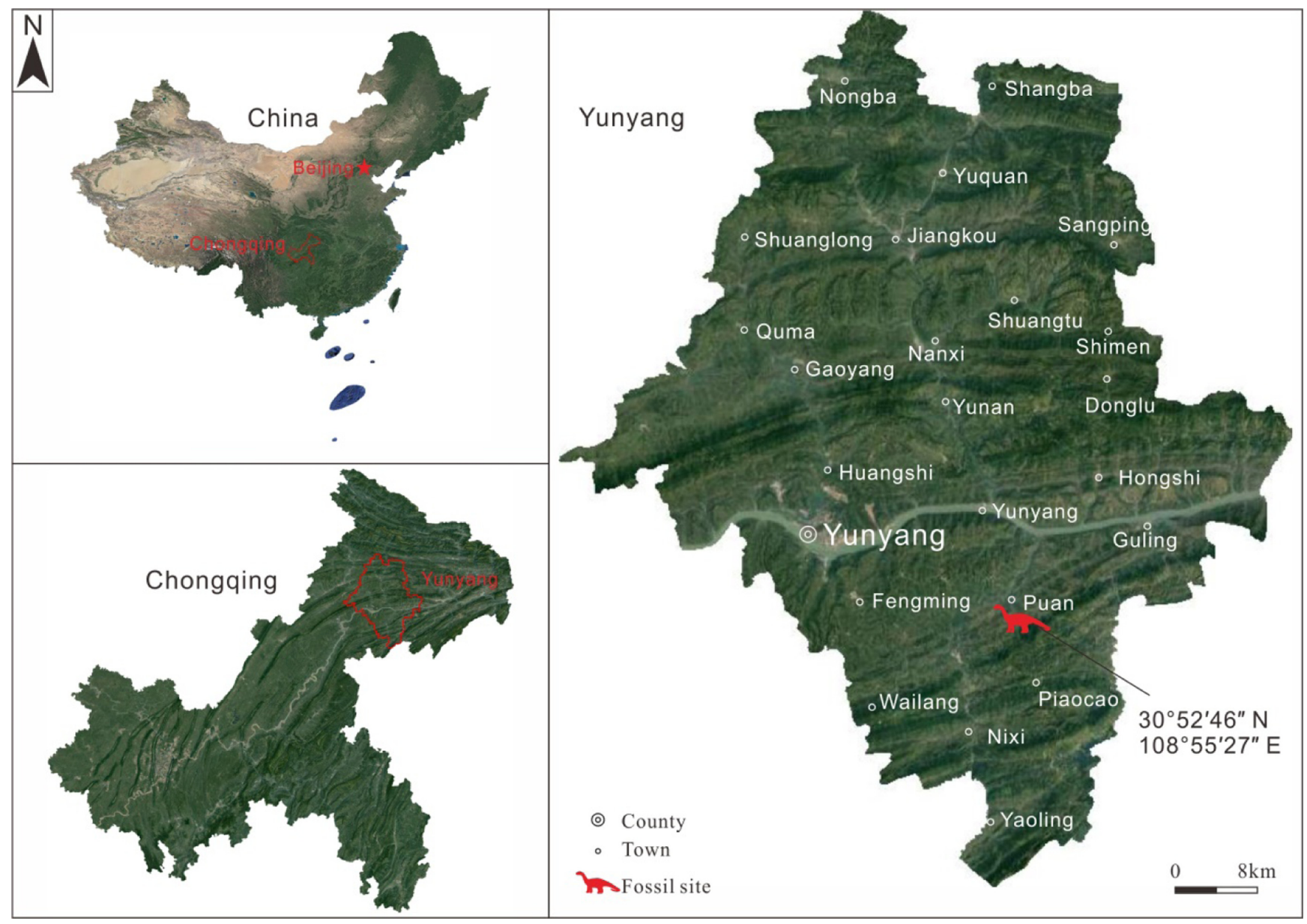

Figure 1. Map of China showing the location of the Puan dinosaur fossil geosite on a Google Earth satellite image.

succession of deposition is subdivided into nine formations by epoch and lithologic character, which the dinosaur fossils bearing beds from the Middle Jurassic Xintiangou Formation and Lower Shaximiao Formation (Fig. 2). The Xintiangou Formation bears dinosaur bones, turtles, and fish fossils, while the Lower Shaximiao Formation only bears dinosaur bones. Compared to the Lower Shaximiao Formation, the underlying lower Middle Jurassic Xintiangou Formation has produced few dinosaur fossils (Dai et al., 2020a). Due to its fossils content, this area has been proposed as a national geological park.

So far, ten fossil sites have been found in this area (beds from the Xintiangou Formation and the Lower Shaximiao Formation, based on communication with the staff of the No. 208 Hydrogeological and Engineering Geological Team), and fossil site one and fossil site four located in Laojun village are the most abundant.

Therefore, we selected fossil site one and fossil site four as the objects of this research (Fig. 3), and investigate their burial backgrounds by studying the sedimentary environment of their strata, and the value of their geosites.

\section{Methodology}

In this study, the fossil burial environment was analyzed mainly through profile and field surveys. A total of three geological sections were measured in the area, which is shown in Fig. 2. Based on the measured sections, the sedimentary environment of the fossil burial site was analyzed in combination with the characteristics of lithology assembly. Combining with the previous research results, the scientific and socio-economic values of the dinosaur fossil geological remains were discussed.

\section{Results and Discussion}

\section{Dinosaur Fossil Site One}

The fossil-bearing bed from the Lower Shaximiao Formation is located on a hillside approximately 350 meters west of Laojun village and is named fossil site one (Fig. 3). A purplish-red argillaceous siltstone of Middle Jurassic age can be seen at this site by excavating a well-exposed outcrop (Fig. 4). The dinosaur fossils located at this site are abundant and varied in category, they are distributed over a range of nearly 1,000 square meters, and part of the material has been removed in the early stage of assembly. At present, most of the almost isolated fossil bones are preserved in the outcrop.

Along this outcrop, huge dinosaur bone fossils are clearly visible, juxtaposed and superimposed, including more than 1,500 pieces (including bone blocks) (Fig. 5). Based on their morphology and the occurring strata, these vertebrate fossils are identified as the bones of sauropod, 

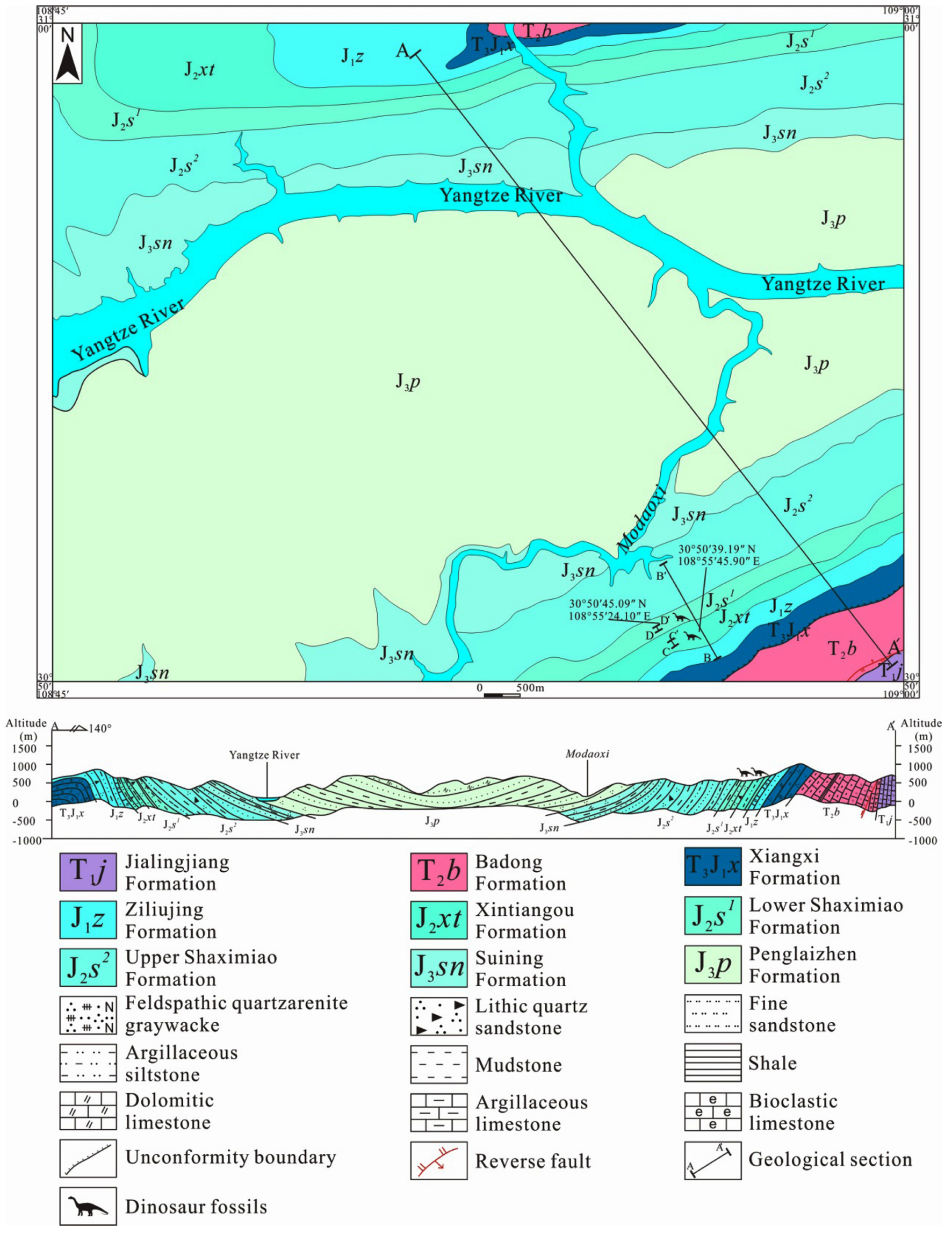

Figure 2. Regional geological map of Yunyang County, Chongqing Municipality, China (modified from 1:50,000 regional geological survey reports of Yunyang County, Chongqing Municipality, China). 

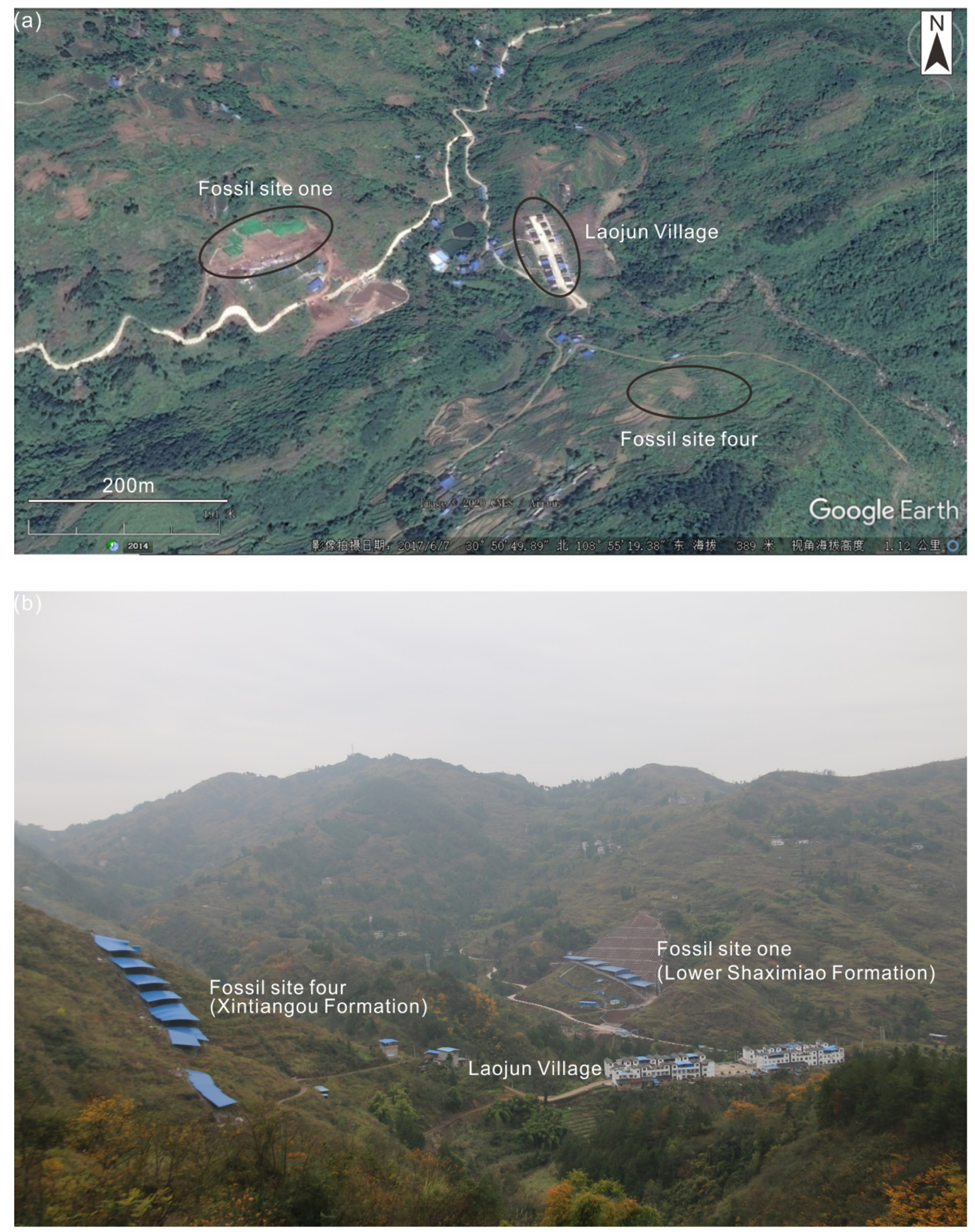

Figure 3. (a) The location of the fossil geosite on a Google Earth satellite image; and (b) photograph of the macroscopic appearance of the fossil geosite. 


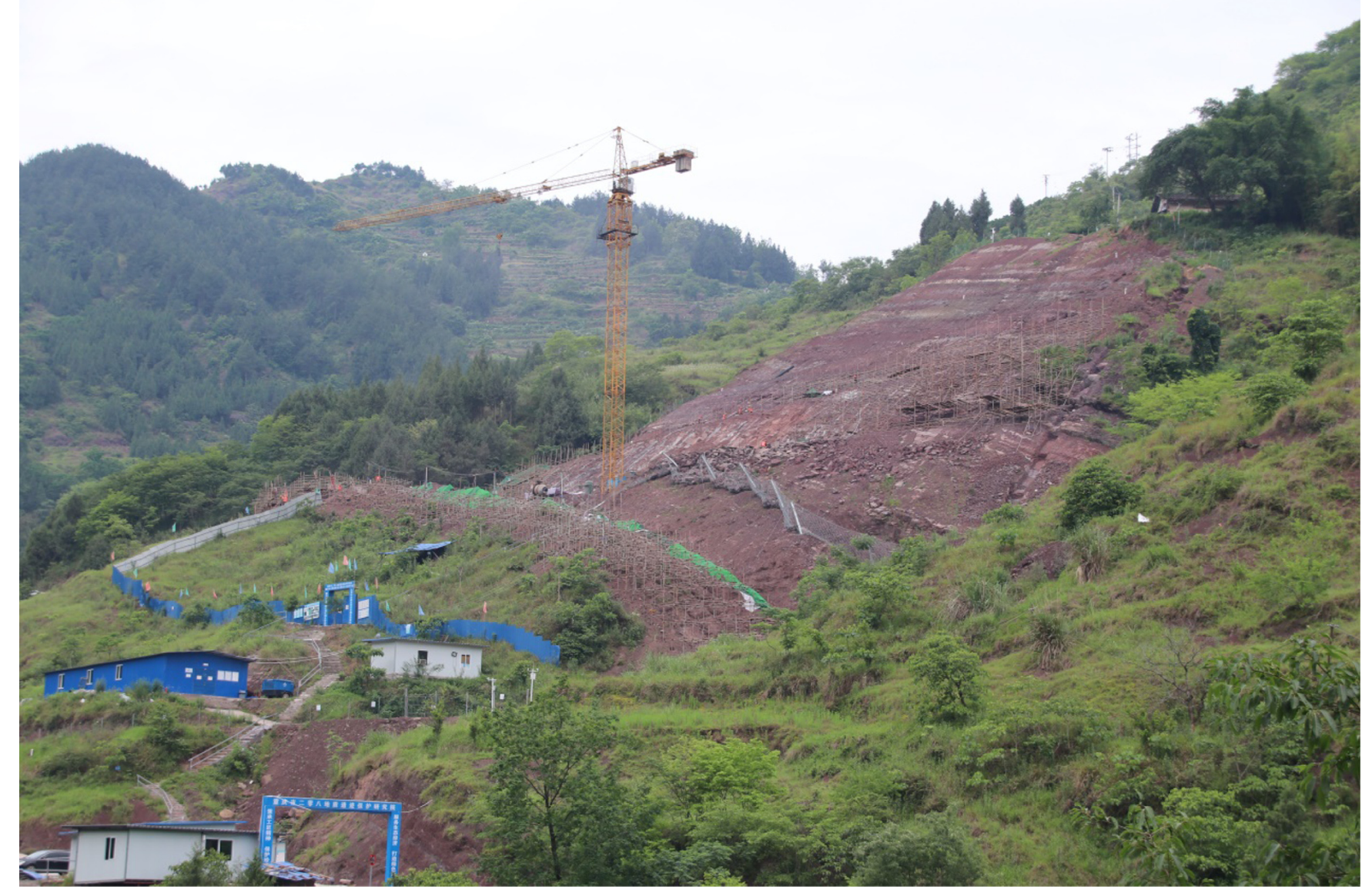

Figure 4. Excavated outcrop in the Lower Shaximiao Formation.

theropod and ornithopod dinosaurs (communication with the staff of the No. 208 Hydrogeological and Engineering Geological Team).

The fossil wall dinosaur bones are disorderly distributed, without obvious orientation, the preservation is generally poor. Most of them are isolated bones with no obvious striations on the surface of bones, and no traces of biological damage have been found. The large-scale accumulation and burial of skeletons indicate that it is a sudden rapid burial event. The bones are scattered and poorly preserved, indicating that the sediments have huge energy during the burial process (such as debris flow).

We measured the geological section of this area and carried out sedimentary facies analysis (see subsequent articles from the team for detailed analysis and specific research results) to build a profound understanding of the character of the lithology and burial environment of the dinosaur fossils (Fig. 6) (for the site of the geological section see BB' and DD' in Fig. 2).

Fossil site one is located in the Lower Shaximiao Formation. From the perspective of petrostratigraphic assemblages, the underlying strata is the Xintiangou Formation. The Xintiangou Formation is a littoralshallow lacustrine environment on the whole (Zhou et al., 2020). Dark shale is developed to varying degrees in the middle parts (Fig. 7a), charcoal and plant fragments are occasionally seen in the sandstone (Fig. 7b), and shell beach is developed in the middle part (Fig. $7 \mathrm{c}$ ), which represents a warm and humid sedimentary environment (Deng et al., 2017).
The overlying strata of the Lower Shaximiao Formation is an interbedding of gray fine-grained quartz sandstone and purplish-red argillaceous siltstone with an unequal thickness (Fig. 8a). The shape of tabular sand and its parallel bedding (Fig. $8 \mathrm{~b}$ and c) indicates that it is a typical fluvial facies sedimentary feature (Jo and Chough, 2001). Calcareous nodules are developed in purplish red argillaceous siltstone (Fig.8d and e), indicating that the paleosol in this area is developed (Smith, 1995), the paleoclimate is relatively arid and has experienced intermittent exposure (Zhang et al., 2016).

Compared with the Xintiangou Formation, the Lower Shaximiao Formation is also a typical fluvial deposit, which is reflected in the wedge-shaped sand body and parallel bedding (Fig. 9a and b). At the same time, calcareous nodules can also be seen in the Lower Shaximiao Formation (Fig. 9c), but the size and quantity are significantly smaller than those in the upper member. These characteristics suggest that the sedimentary environment has been transformed. From the macroscopic changes in the sedimentary assemblage, the sedimentary environment of the Lower Shaximiao formation is a transitional environment from the relatively wet lake sedimentary environment of the Xintiangou Formation to the arid and hot flood plain of the Upper Shaximiao Formation.

We measured the geological section of fossil site one (for the site of the geological section see DD' in Fig. 2) (Fig. 10). The lithological combination and sedimentary structure of the profile show that it is a set of typical fluvial deposits. Dinosaur fossils are buried in purple- 

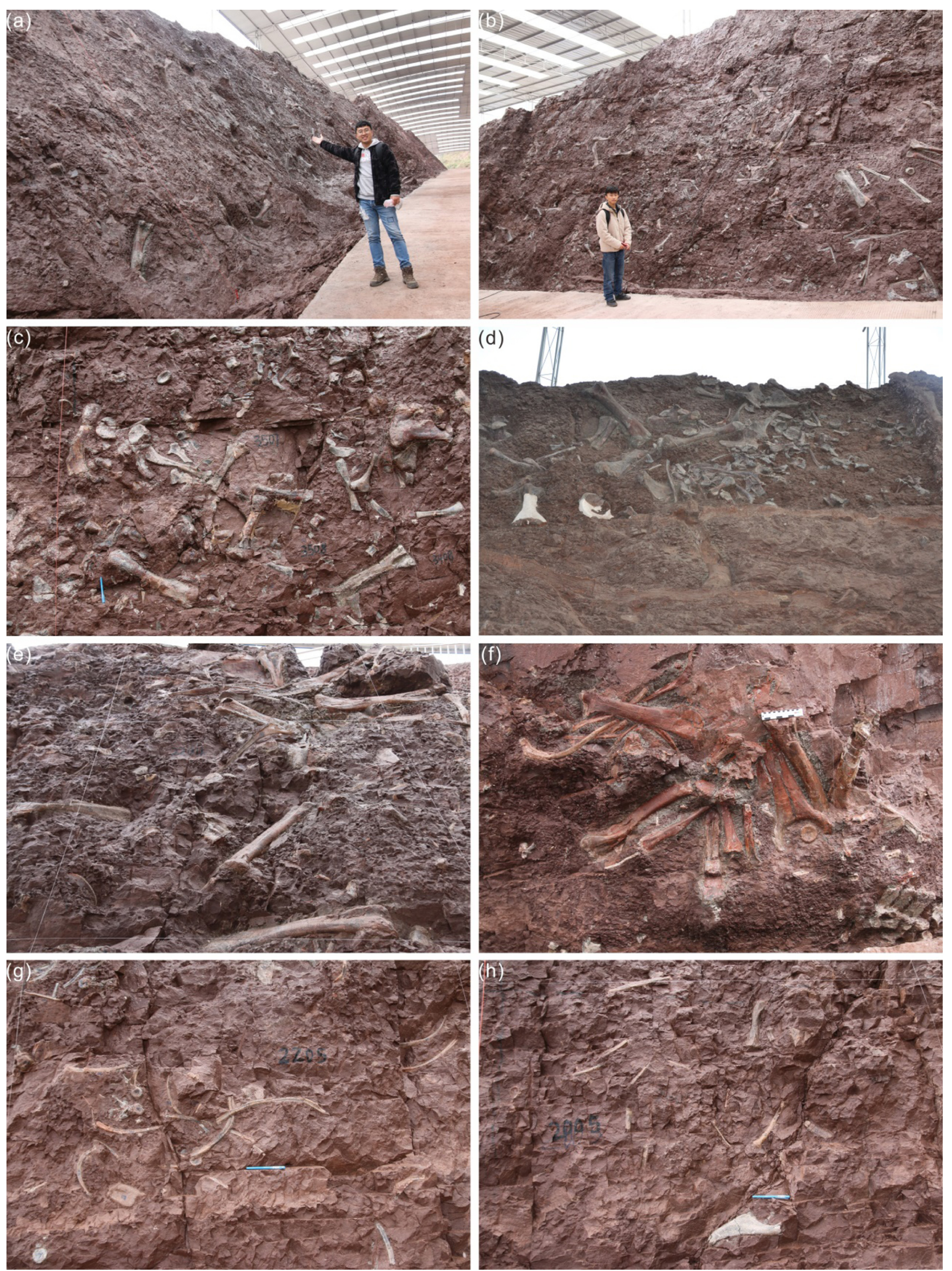

Figure 5. Abundant dinosaur bone fossils excavated in the fossil site one. 


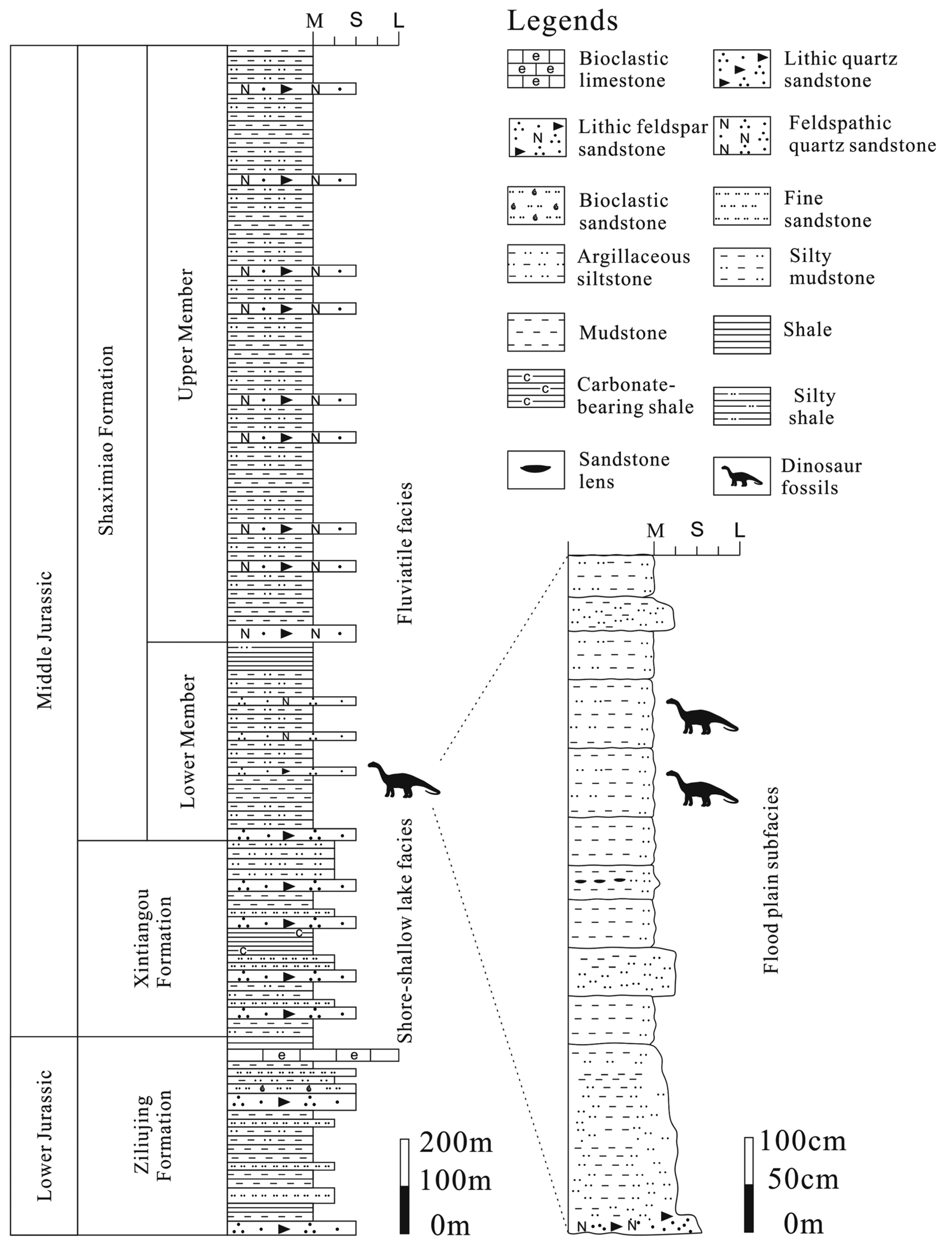

Figure 6. Stratigraphic chart of Laojun village, Puan township, Yunyang County, Chongqing Municipality, China (modified from Li et al., 2019). 

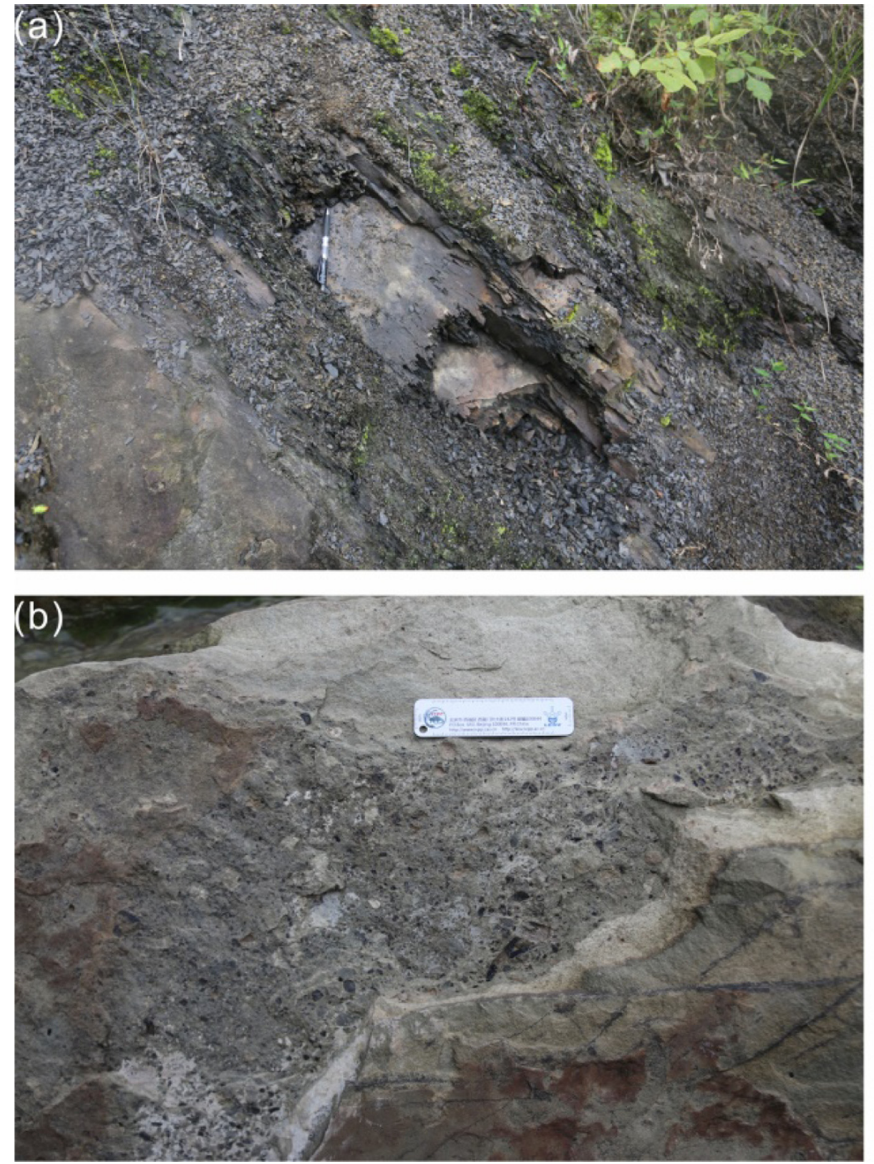

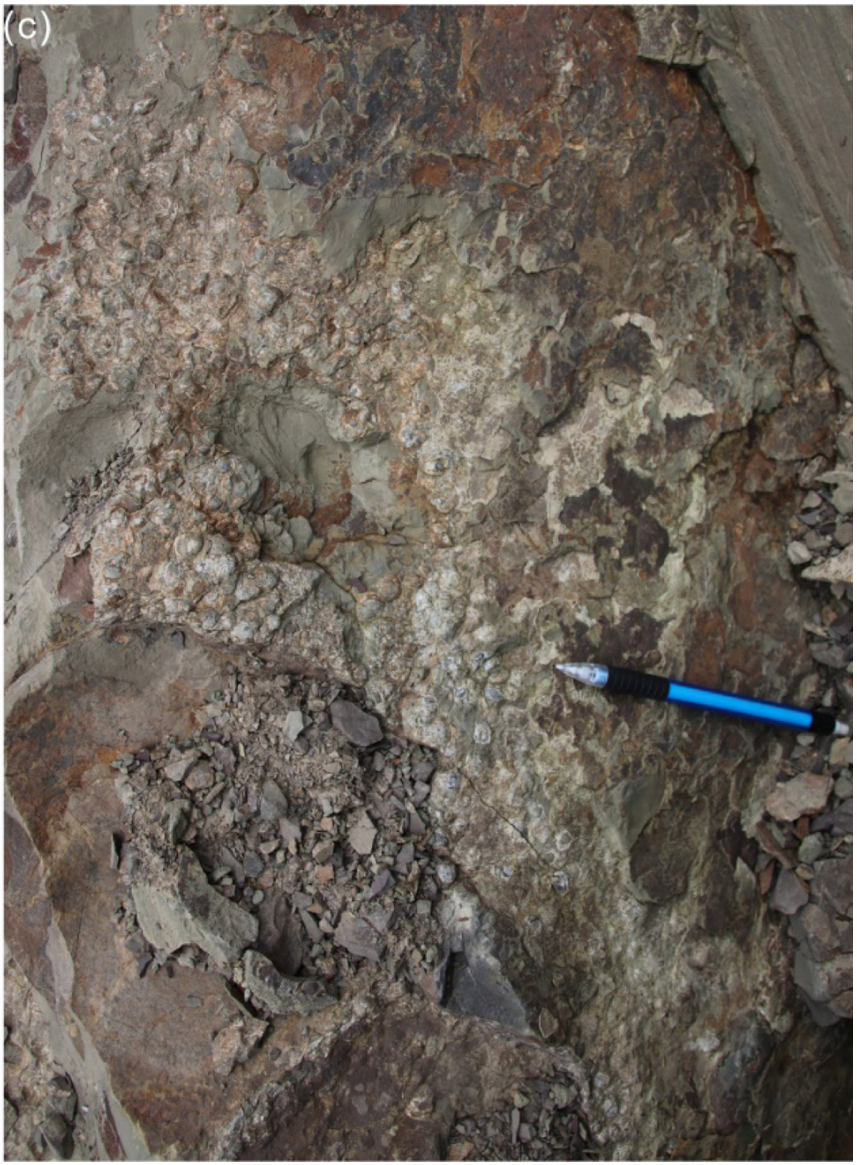

Figure 7. (a) Dark shale; (b) charcoal in sandstone; and (c) shell beach in shallow lake mud.

red argillaceous siltstone in the middle of the section. The color of the rocks, exposure marks, and geochemical characteristics indicate that the sedimentary period experienced an alternation of relative humidity and drought (Zhang et al., 2020).

According to the sedimentology analysis of the adjacent layers of the fossil wall, the gravity sedimentary structure in the area is more common and has the typical characteristics of liquefaction, including water-escape structures (Fig. 11a), cross bedding and deformed bedding (Fig. 11b), argillaceous rubble (Fig. 11c), mud diapers (Fig. 11d), sand veins (Fig. 11e), and mud veins (Fig. 11f). The above sedimentary tectonic assemblage indicates that the deposition is rapid in the area, which is the event deposits under the normal river sedimentary environment (see subsequent articles from the team for detailed analysis and specific research results).

It is worth noting that a sedimentary tuff intercalated bed has been found below the buried horizon, at a distance of 17 meters (Fig. 12). Under the microscope, the rock flakes were identified as lithic crystal tuff. We have also carried out U-Pb dating work on the sedimentary tuff, and thise related work is still in progress.

In the Sichuan Basin, the sedimentary strata mainly consist of a series of reddish clastic rocks during the Jurassic period, and they are deposited in a large lake and plain river. The Lower Shaximiao Formation is mainly a series of deposition in the river environment, and the climate is mainly subtropic semiarid and arid (Wang et al., 2010). We drew a paleogeographic map of the sedimentary pattern of fossil site one (Fig. 13). It was considered that fossil site one was buried as a result of a diluted debris flow, possibly triggered by surrounding volcanic activity. Dinosaurs living in the flood plain were buried rapidly by the diluted debris flow after death and then with the diagenesis of sediments, their bones were transformed by physical and chemical processes to form fossils.

\section{Dinosaur Fossil Site Four}

Fossil site four is located on a hillside approximately 250 meters south east of Laojun village (Fig. 3). Clastic rocks and limestone of Middle Jurassic age can be seen at this site by excavating a wellexposed outcrop (Fig. 14). The fossil bearing bed from the Xintiangou Formation, was excavated to the surface.

Compared to the Lower Shaximiao Formation, this formation has produced few vertebrate fossils (Dai et al., 2020a). The fossils in this site have been removed and sent to the Chongqing Laboratory of Geoheritage Protection and Research, so there were no fossils on the outcrop, however, with the establishment of the geopark, we may eventually observe the fossils from this site. Based on communication with the staff of the 208 Hydroge-ological Engineering Geological Team, this geosite bears dinosaur bones, turtles, and fish fossils.

We measured the geological section of this area to build a profound understanding of the character of the lithology and taphonomic environment of the dinosaur fossils (Fig. 15) (for the site of the profile 

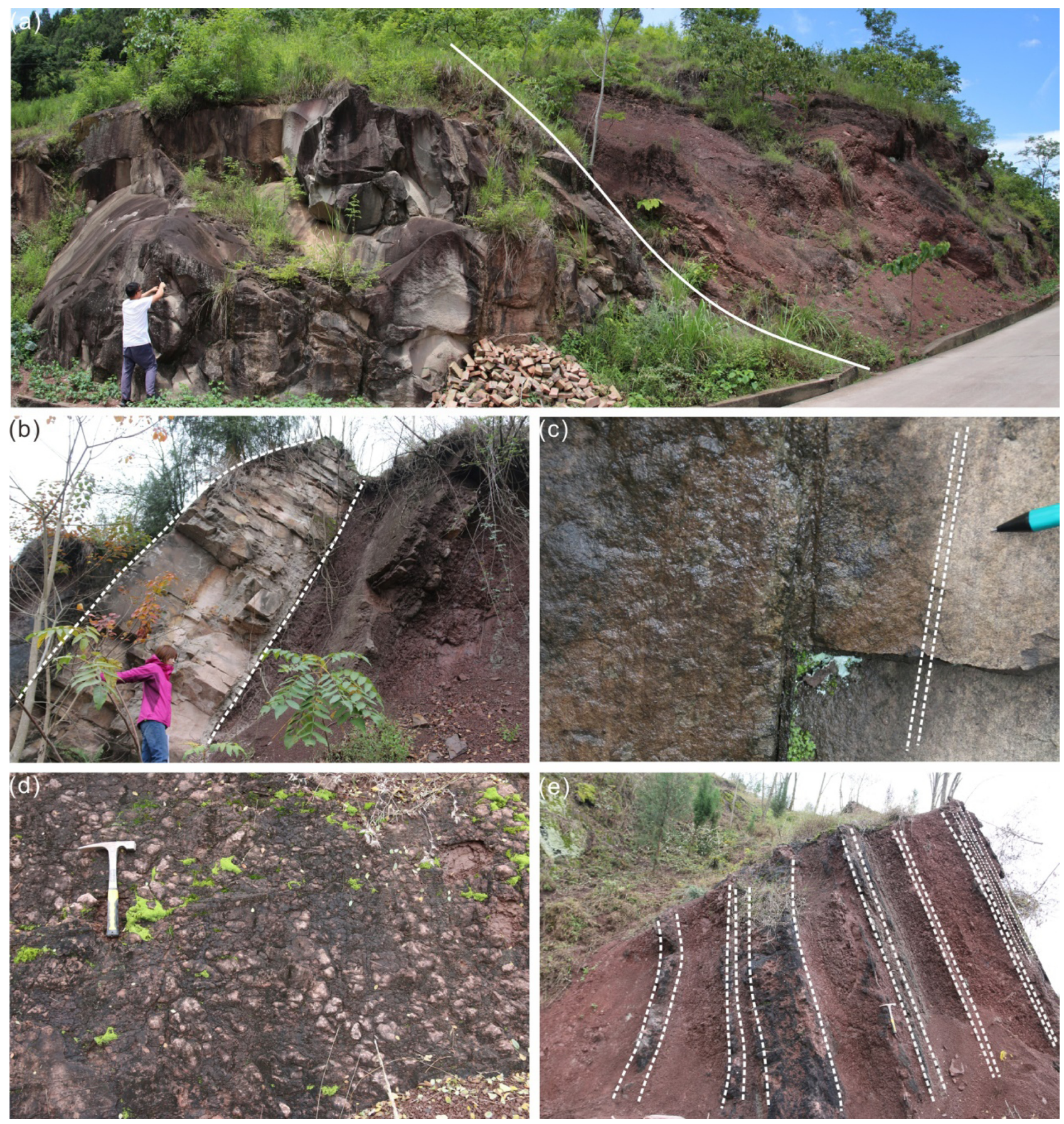

Figure 8. (a) Vertical accretion of flood plain and sand -wedge of the bank, in the outcrop. (b) Scour surface under the tabular sand, the typical binary structure of fluvial facies. (c) Parallel bedding, reflecting at unidirectional flow. (d) Calcareous nodules and (e) calcareous nodule layer, representing a pattern of being exposed and eroded repeatedly.

see BB' and CC' in Fig. 2).

When describing the sedimentary environment of fossil site one, the overall sedimentary background of the Xintiangou Formation has been introduced, i.e., the Xintiangou Formation as a whole is a product of lake sediments in a warm and humid paleoclimate. We also found that the sedimentary environment of the Xintiangou Formation fluctuated during this period, with alternating lake surface expansion and shrinkage of the paleolake. This is well documented in the sediments of the Xintiangou Formation. We believe that the sedimentary environment of the Xintiangou Formation may have the following alternating evolution: lakeside-lake delta (flooding) - lakeside - shallow lake-lake delta (flooding) (Fig. 16).

Fossil site four also contains terrestrial and aquatic nonmarine fossils, so the burial environment of fossil site four has aroused interest. Based on careful analysis of the surrounding rock and sedimentary structure of this fossil site, we think that it is a lakeside burial environment (Fig. 17). As partial dinosaur bones are interconnected (Dai et al., 2020a; Li et al., 2019), the burial type of this dinosaur fossil site may have been 

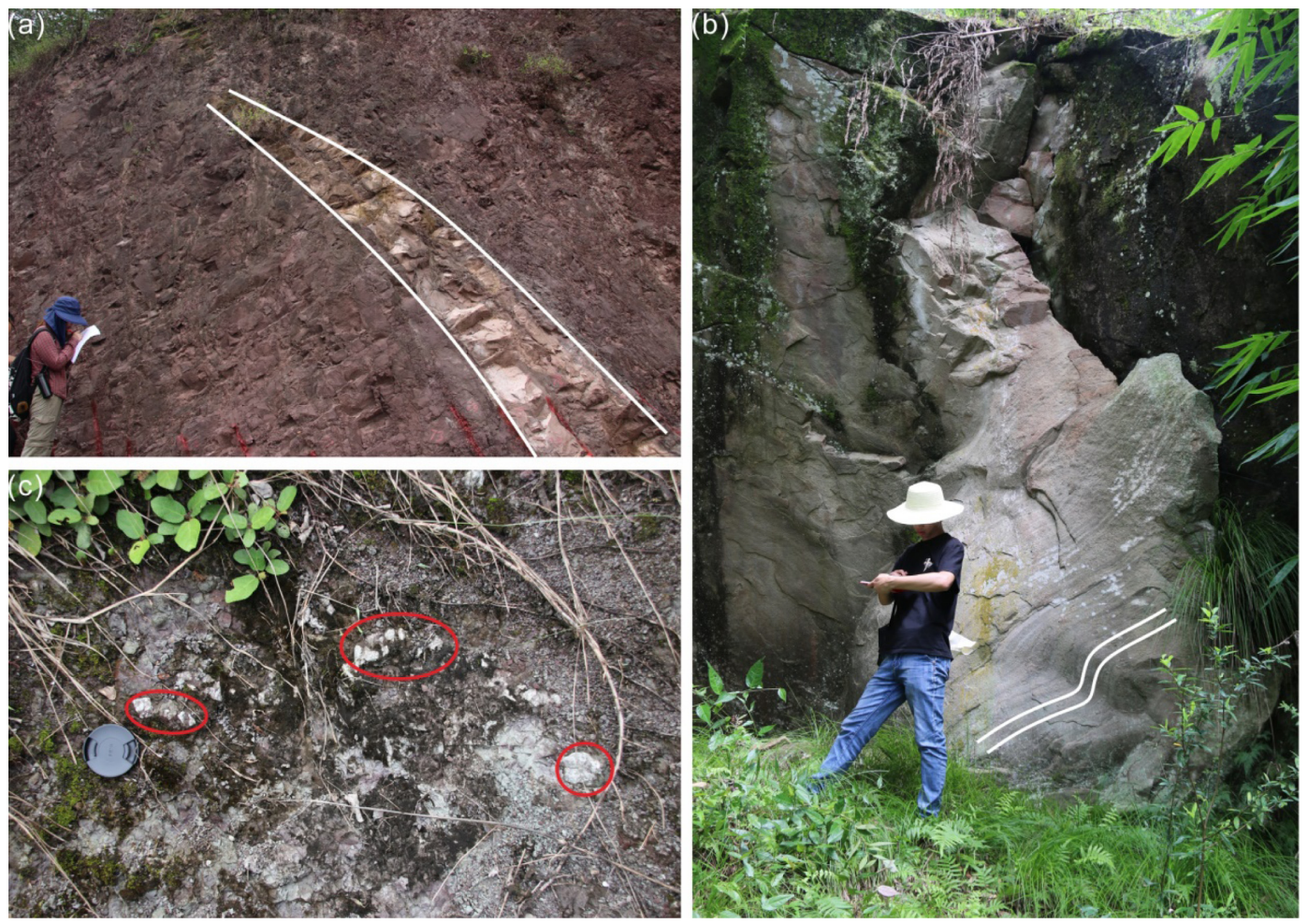

Figure 9. (a) Wedge sand, (b) parallel bedding and (c) calcareous nodules which representative characteristics of the sedimentary rock of the Lower Shaximiao Formation.

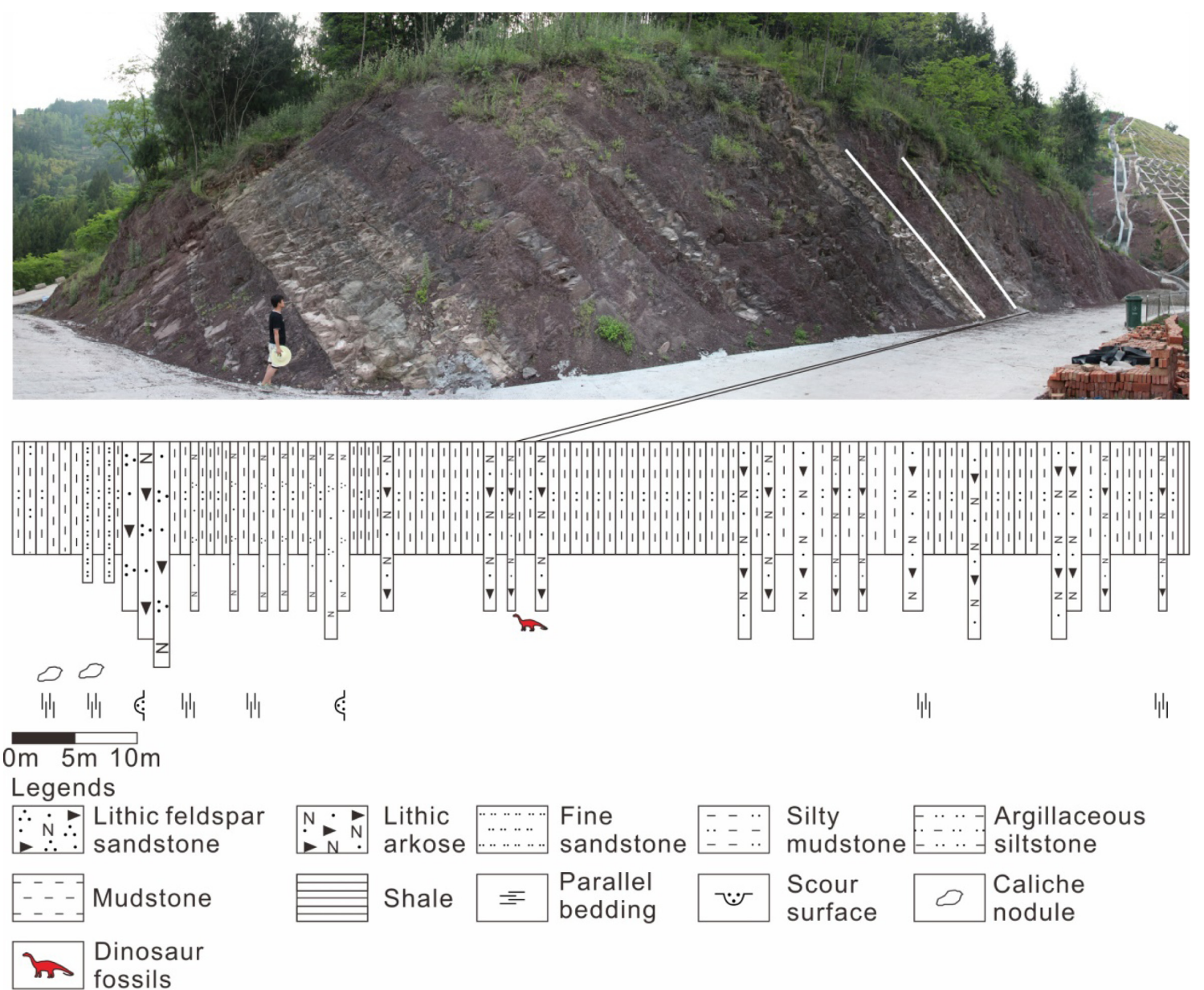

Figure 10. The lithological column of the geological section and a picture of the outcrop. 

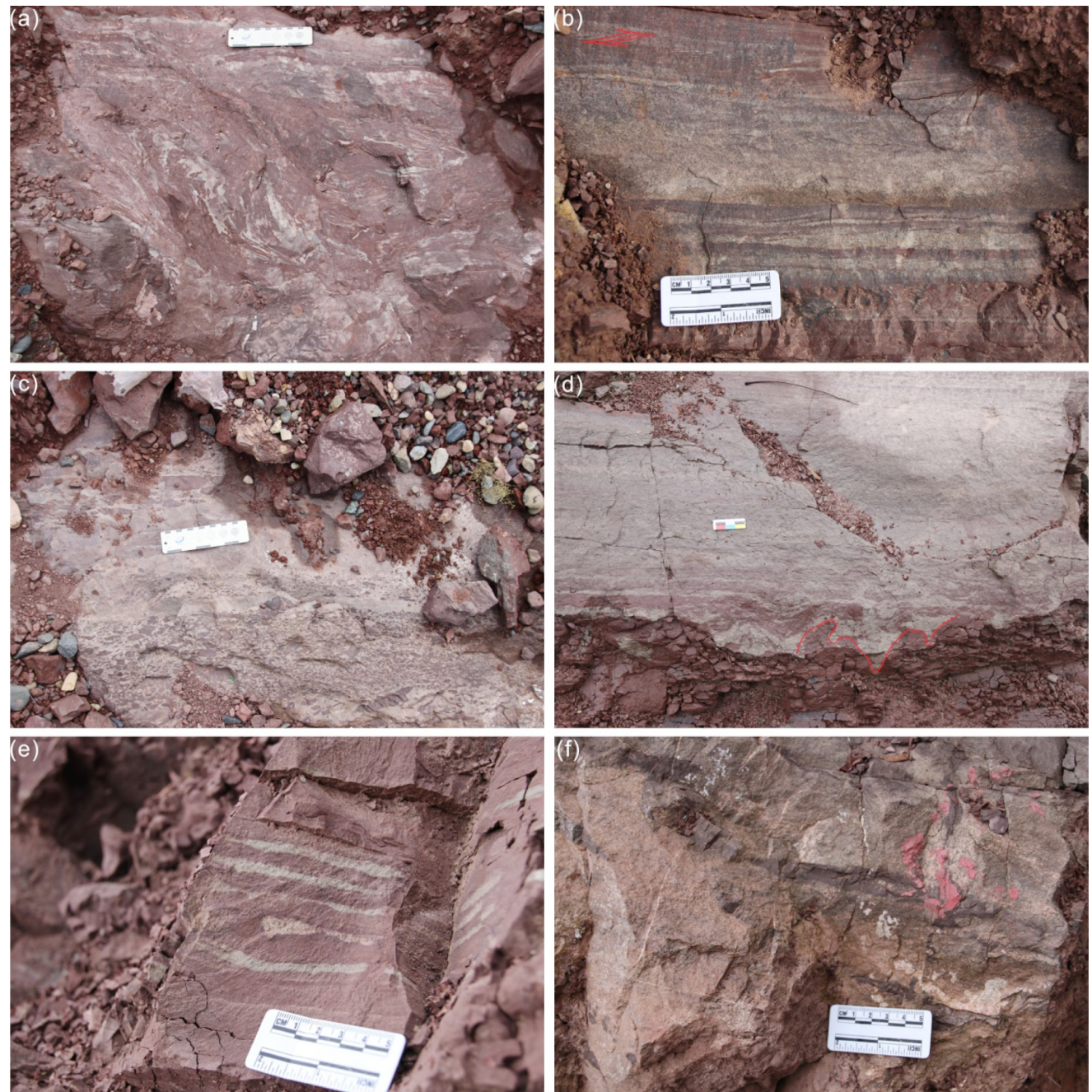

Figure 11. Typical gravity sedimentary structure of the Lower Shaximiao Formation. (a and c-f) reflects the rapid accumulation of sediments, and (b) cross bedding reflects the fluvial environment.

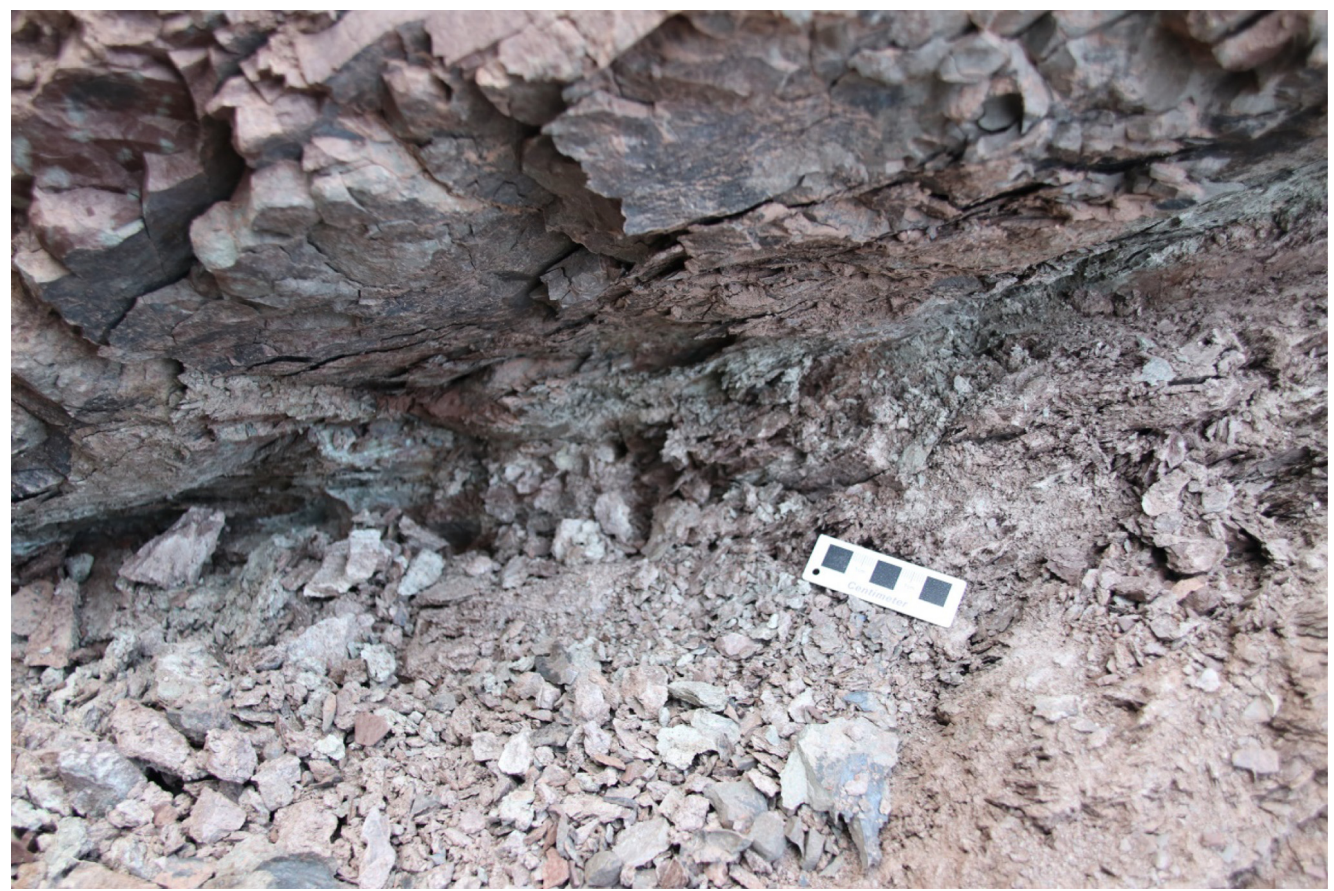

Figure 12. Sedimentary tuff intercalated bed. 


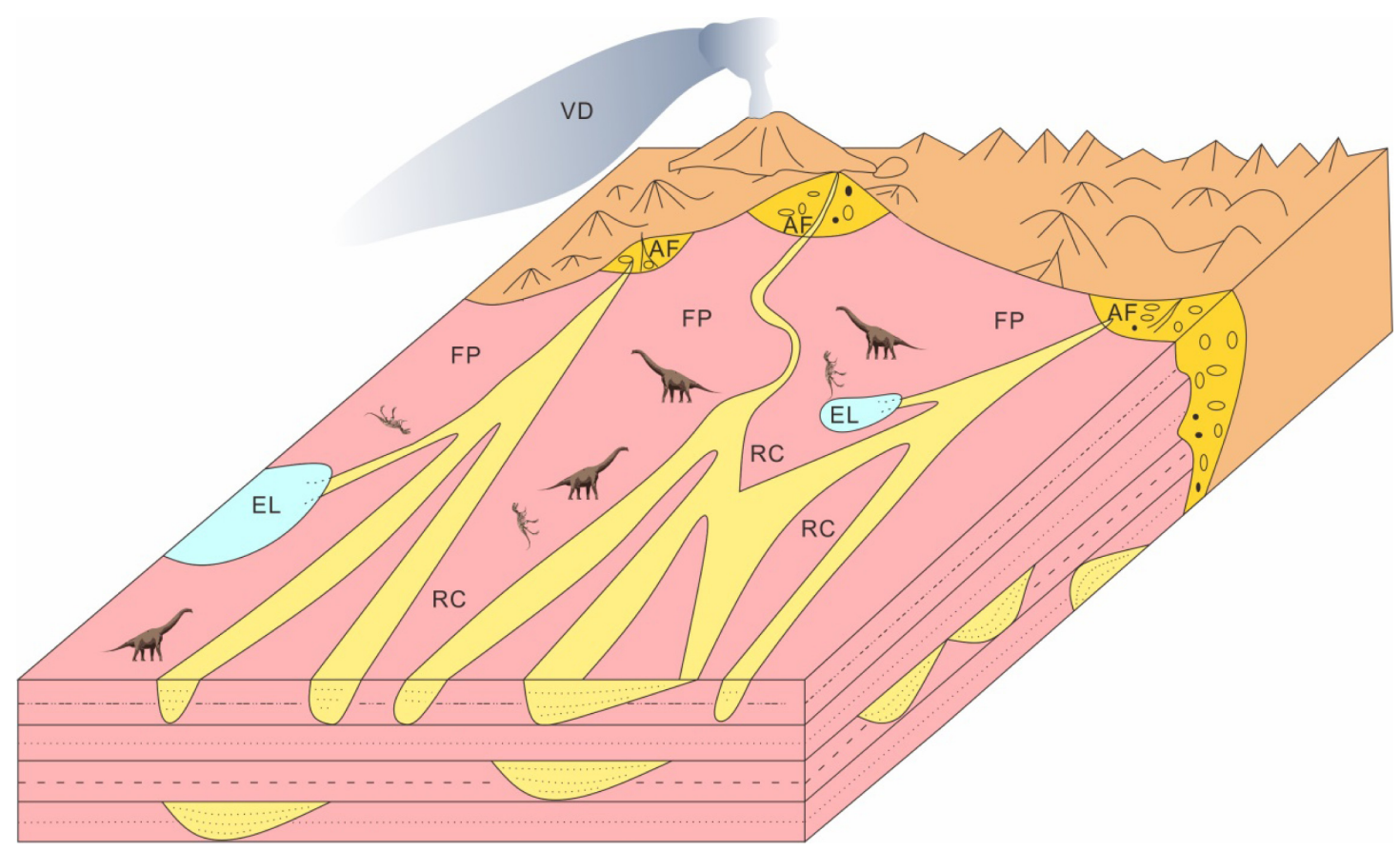

Figure 13. Paleogeographic map of the sedimentary pattern of the Lower Shaximiao Formation. AF-Alluvial fan, EL-Ephemeral lake, FPFlood plain, RC-River channel, VD-Volcanic dust.

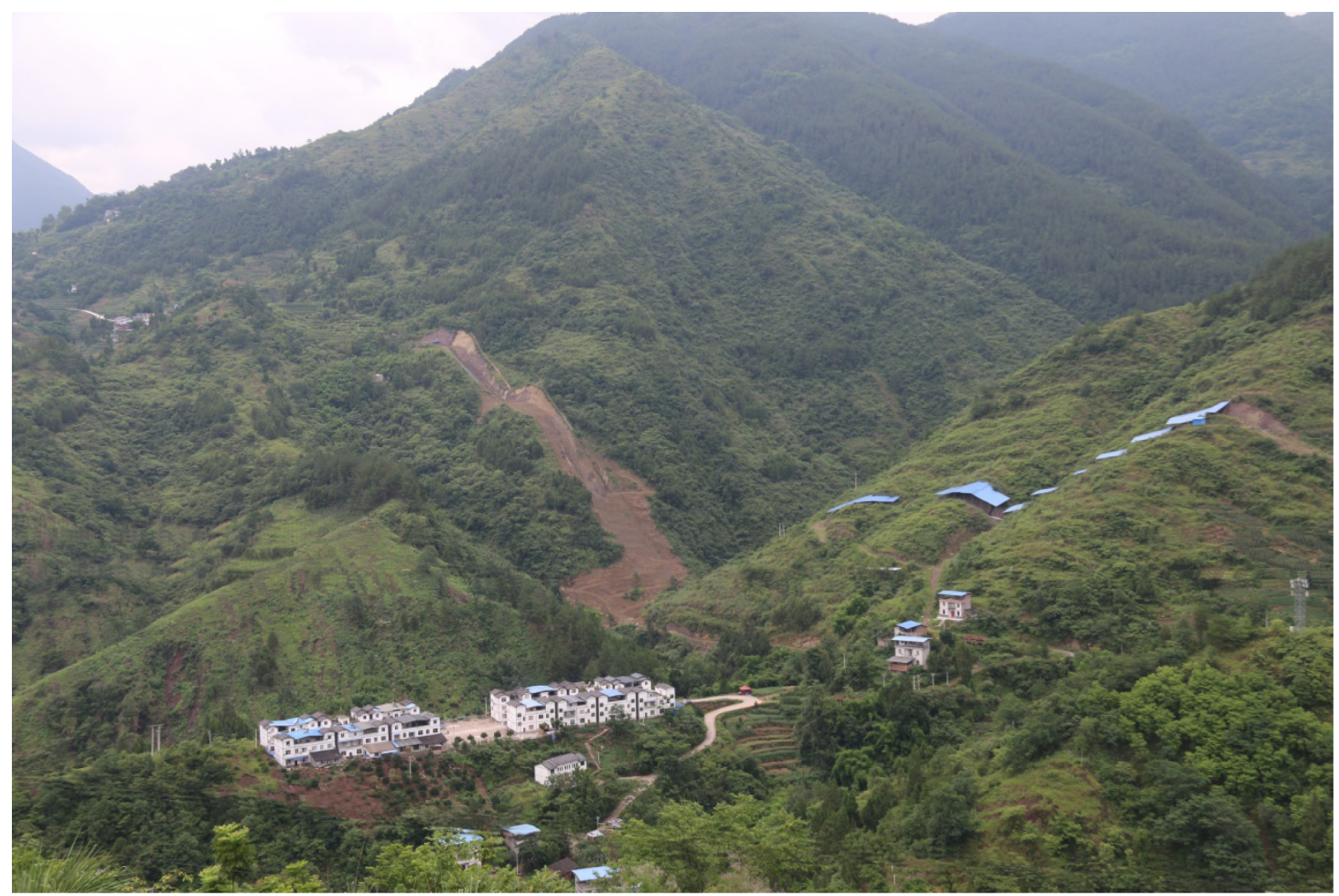

Figure 14. Excavated outcrop in the Xintiangou Formation.

hypoautochthonous burial. The dinosaur bones may have been transported from land into the lake at a short distance.

In the Sichuan Basin, the Xintiangou Formation of sedimentary characteristics shows the uplift processes of the lakebed, and the lake depth changed to shallow. In the northeastern Sichuan Basin, the sedimentary environment is mainly a river system and changed to the vicissitudinous intermittent lake and lake delta (Wang et al., 2010).
We drew a paleogeographic map of the sedimentary pattern of fossil site four (Fig. 18). It was considered that after the dinosaurs living in the flood plain died, that close range transport of their bodies was provided by rivers to the lakeside delta and then with the diagenesis of sediments, their bones were transformed by physical and chemical processes to form fossils. 


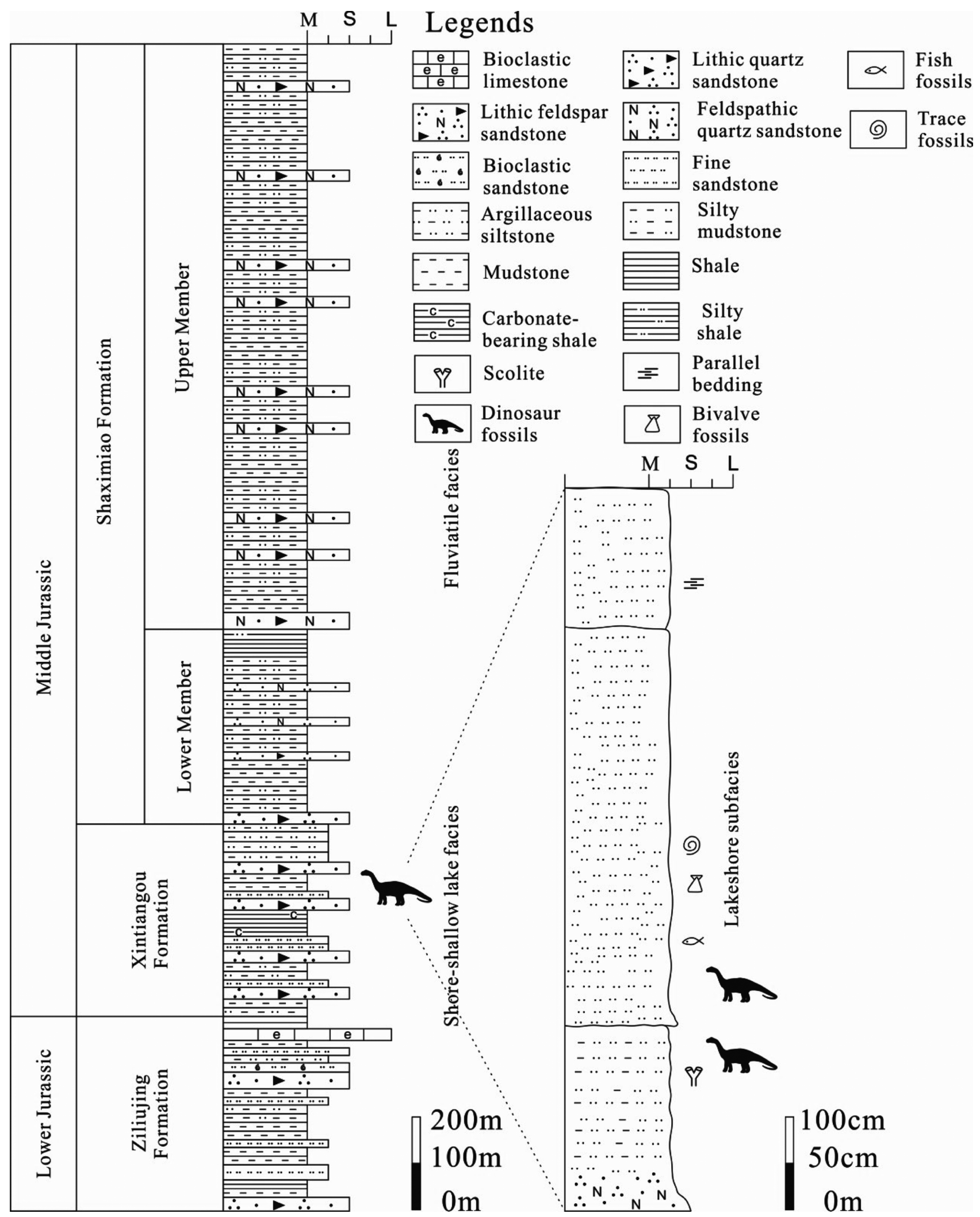

Figure 15. Stratigraphic chart of Laojun village, puan Township, Yunyang County, Chongqing Municipality, China (modified from Li et al., 2019).

\section{Geoheritage Values of the Dinosaur Bone Fossils}

This unique geoheritage has a huge paleontological value. In this section, we will expound the geoheritage value from two aspects: scientific value and socioeconomic value.

Since the official conservation excavation of dinosaur fossils in 2016, this geosite continues to surprise us. In 2019, a new neornithischian dinosaur, Sanxiasauru modaoxiensis gen. et sp. nov., was described based 

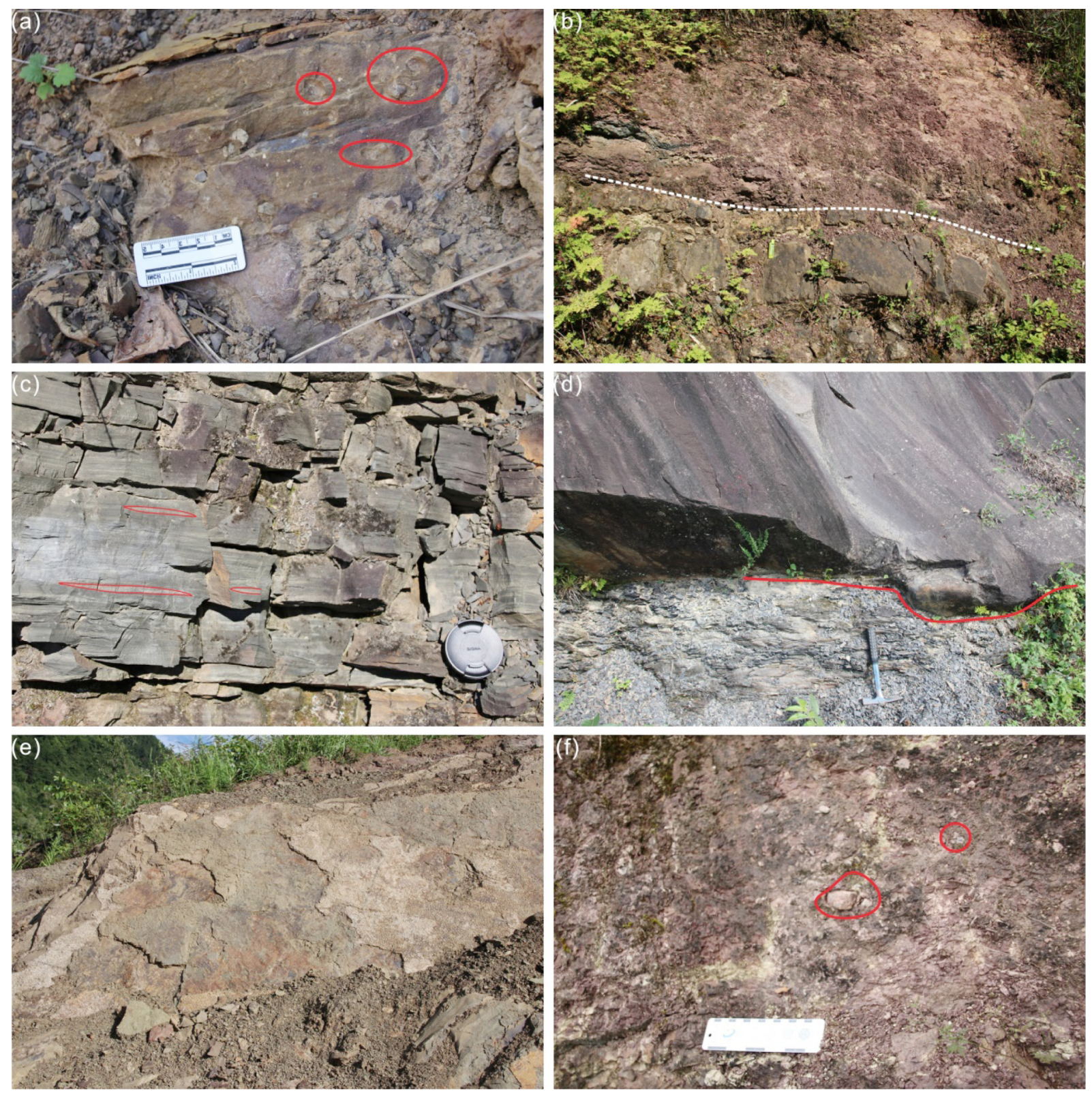

Figure 16. Record of sedimentary environment changes on outcrops in the Xintianggou Formation. The pictures from a to f represents the change from the bottom to the top of the Xintiangou Formation.

on a partial postcranial skeleton from the Xintiangou Formation, which is the earliest record in Asia (Li et al., 2019). In 2020, a new theropod, Yunyangosaurus puanensis gen. et sp. nov., was reported based on a fragmentary specimen recovered from the Xintiangou Formation, which has implications for early tetanuran evolution (Dai et al., 2020a), and a new species of Omeisaurus was reported based on fossils from the Lower Shaximiao Formation, which may provide additional information to help understand the evolutionary history of this genus (Tan et al., 2020). Presently, scientific studies continue, mainly based on taphonomy (paleogeographic, paleoclimate and sedimentology) and morphology, both in previously outcrops (fossil site one, fossil site four) and in those recently discovered. At the 2019 Annual Symposium on Yunyang Dinosaur Fossil Protection and Research, a new dinosaur fauna was proposed based on the dinosaurs discovered in the early Middle Jurassic Xintiangou Formation in this area (Dai et al., 2020b). Also in this symposium, our team interpreted the buried environment of the fossils (see burial environment of fossil site one and four).

The geoheritage of the dinosaur fossils excavated in Laojun village, Puan township, Yunyang County, Chongqing Municipality has attracted much attention. It has received extensive media coverage since the beginning of the excavation. A few representative reports are as follows. On June 28, 2017, a press conference was held in Chongqing on the rescue discovery of dinosaur fossils in Puan township, Yunyang County. On January 21, 2018, the People's Government of Yunyang County held a press conference at the Great Hall of the People in Beijing to formally announce the global solicitation of the master plan for the Chongqing Yunyang Dinosaur Geopark. This series of news reports greatly increased people's acquaintance with Yunyang.

On March 18, 2020, the National Forestry and Grassland Administration issued the notice that proposed to grant Chongqing Yunyang 

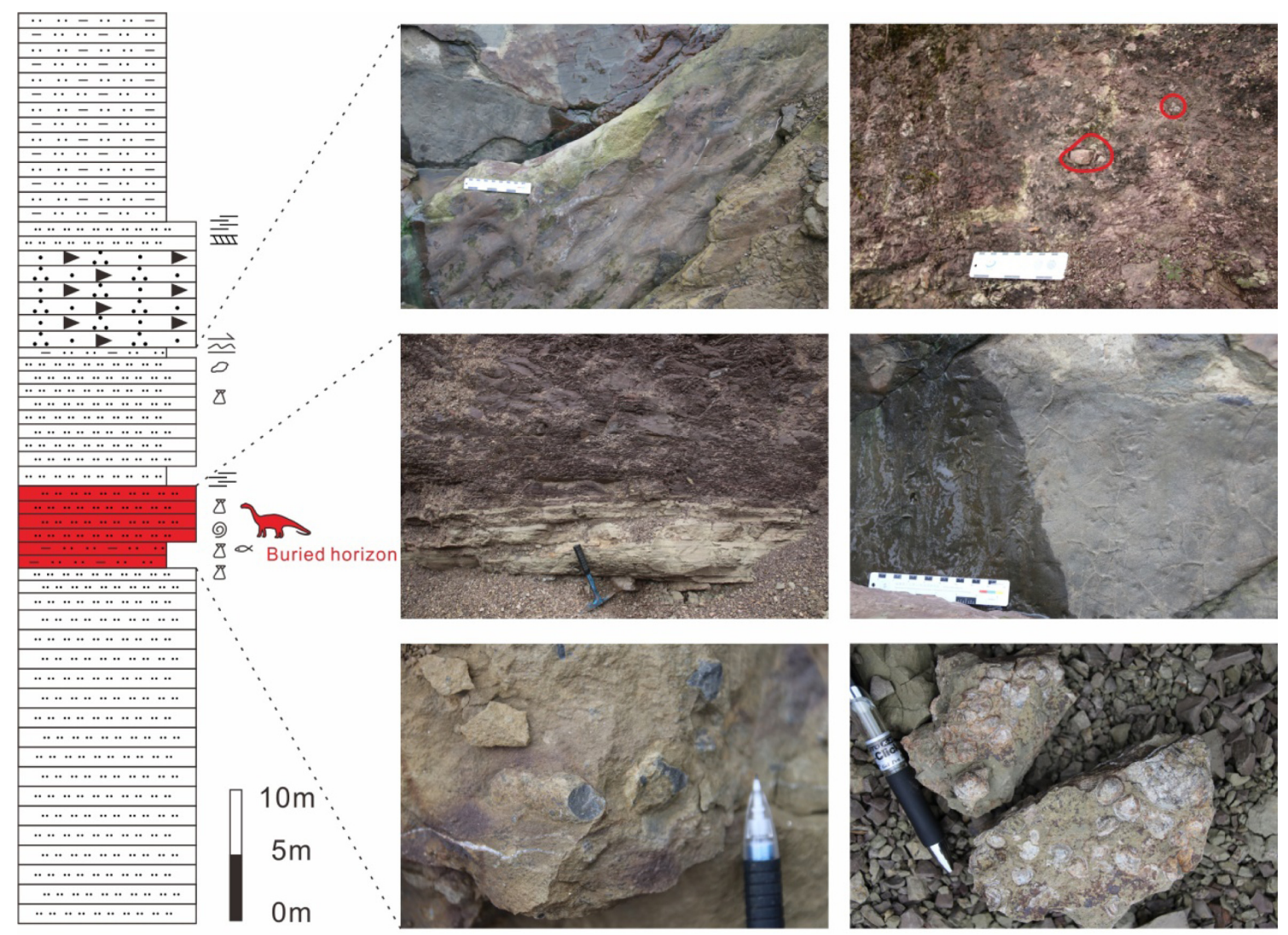

Legends

\begin{tabular}{|c|c|c|c|c|c|c|c|c|c|}
\hline$\therefore \dot{\sim}$ & $\begin{array}{l}\text { Lithic feldspar } \\
\text { sandstone }\end{array}$ & (n) & $\begin{array}{l}\text { Fine } \\
\text { sandstone }\end{array}$ & $\begin{array}{ll}\cdots \cdots \\
\cdots \cdots \\
\end{array}$ & $\begin{array}{l}\text { Argillaceous } \\
\text { siltstone }\end{array}$ & $\equiv$ & $\begin{array}{l}\text { Parallel } \\
\text { bedding }\end{array}$ & III & $\begin{array}{l}\text { Cross } \\
\text { bedding }\end{array}$ \\
\hline$\vec{\simeq}$ & $\begin{array}{l}\text { Ripple } \\
\text { marks }\end{array}$ & 8 & $\begin{array}{l}\text { Bivalve } \\
\text { fossils }\end{array}$ & $\alpha$ & $\begin{array}{l}\text { Fish } \\
\text { fossils }\end{array}$ & & $\begin{array}{l}\text { Dinosaur } \\
\text { fossils }\end{array}$ & (2) & $\begin{array}{l}\text { Trace } \\
\text { fossils }\end{array}$ \\
\hline 0 & $\begin{array}{l}\text { Caliche } \\
\text { nodule }\end{array}$ & & & & & & & & \\
\hline
\end{tabular}

Figure 17. The lithological column of the geological section and outcrop pictures.

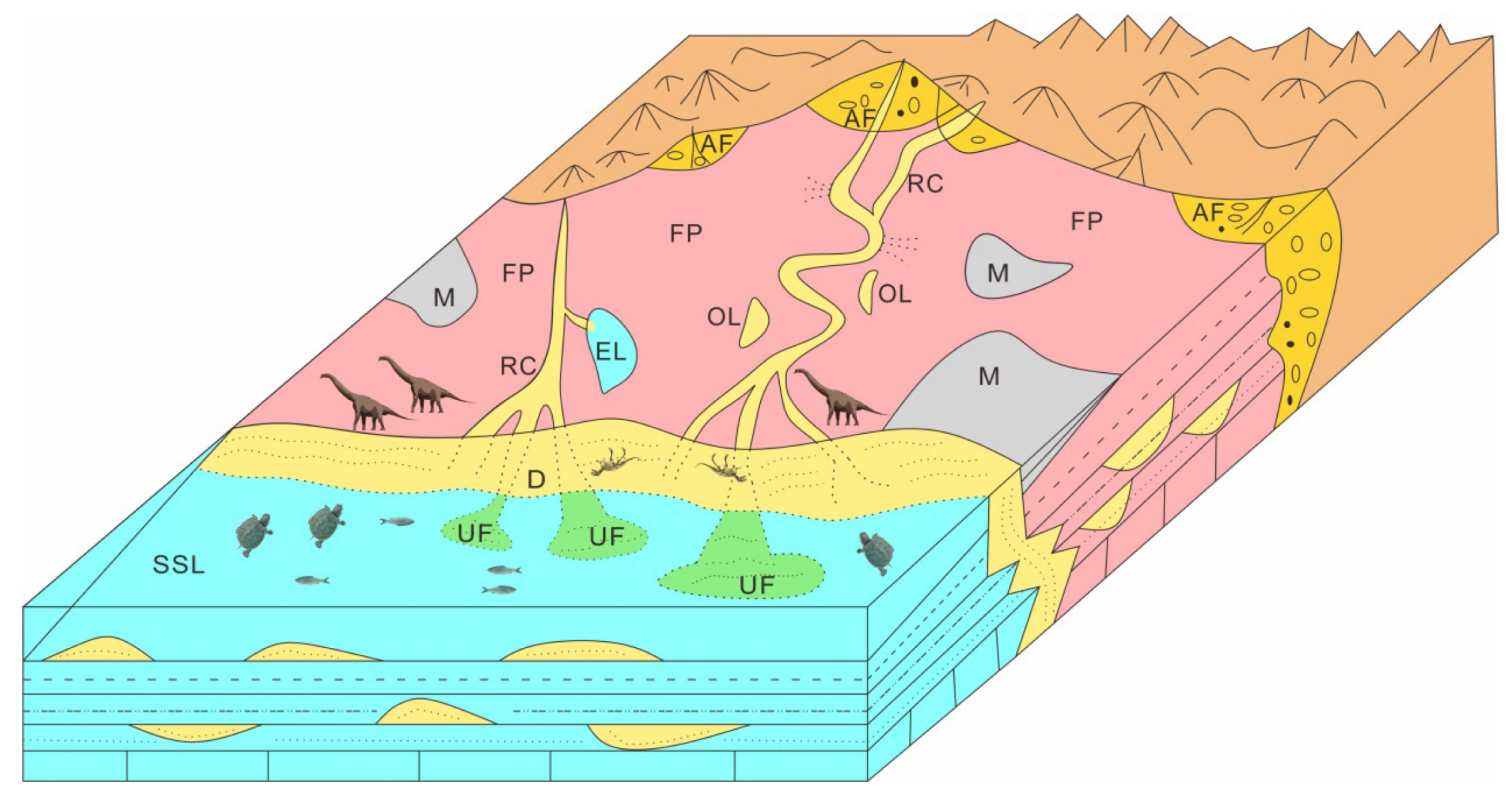

Figure 18. Paleogeographic map of the sedimentary pattern of the Xintiangou Formation. AF-Alluvial fan, D-Delta, EL-Ephemeral lake, FP-Flood plain, M-marsh, OL-Oxbow lake, RC-River channel, SSL-Shore shallow lake, UF-Underwater fan. 


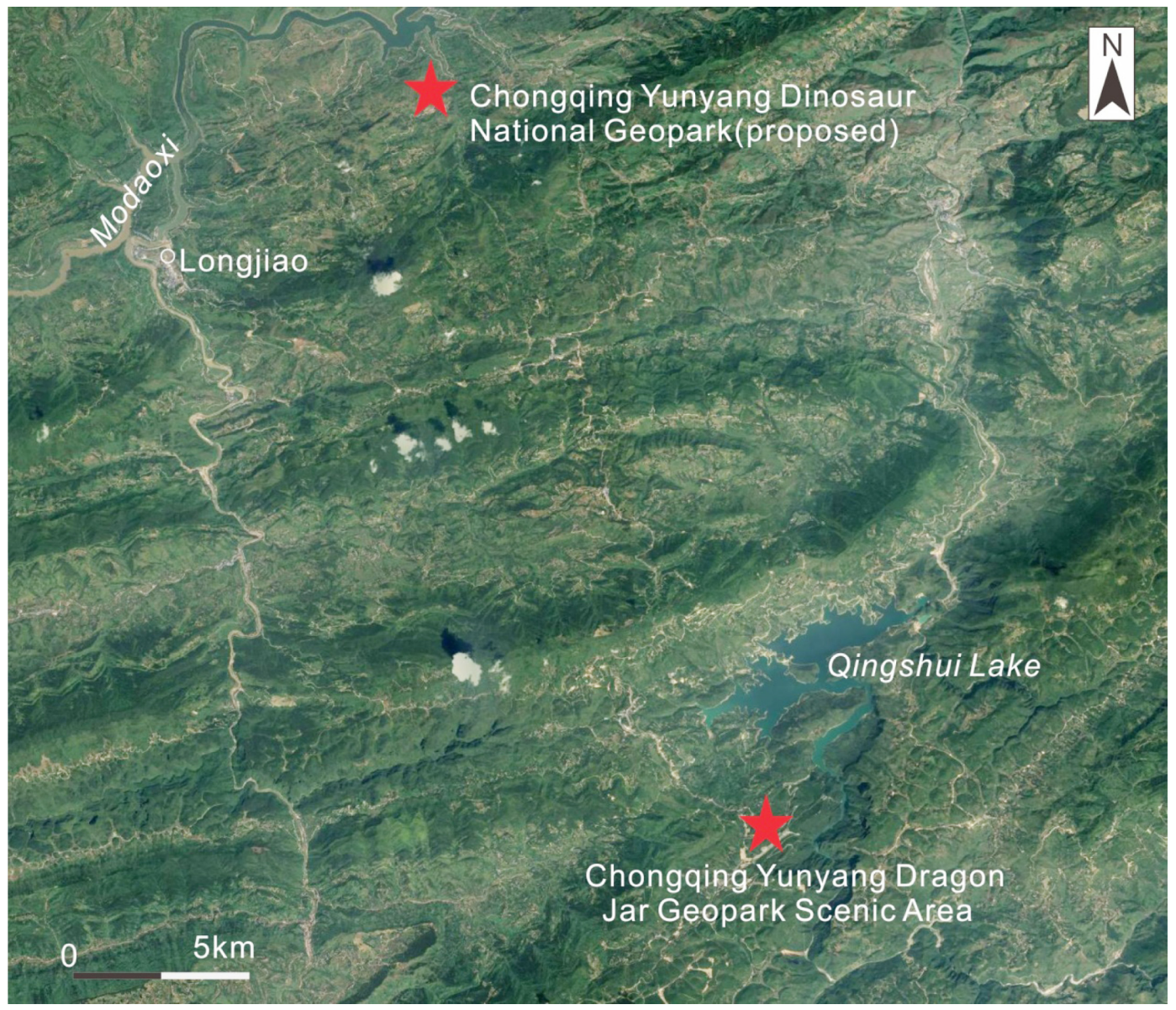

Figure 19. The location of the Chongqing Yunyang Dinosaur National Geopark, which is under construction.

Dinosaur Geopark the qualification of National Geological Park.

The Chongqing Yunyang Dinosaur National Geopark, which is under construction, is located at the node of the Yunyang golden tourism route. Approximately $20 \mathrm{~km}$ southeast of the geopark is the Chongqing Yunyang Dragon Jar Geopark Scenic Area, which is a National AAAAA Tourist Attraction (Fig. 19), thus, this plan maybe further boost the tourism economy of Yunyang County.

\section{Conclusion}

To provide scientific background for the construction of the Chongqing Yunyang Dinosaur National Geopark, the burial environment of geoheritage of dinosaur fossils has been analyzed. The results show that the burial environment between Lower Shaximiao Formation and Xintiangou Formation of the Middle Jurassic is greatly different. The burial environment of the Lower Shaximiao Formation is a flood plain background under a river background, where dinosaur bones were transported and buried by diluted debris flow within a short distance. The Xintiangou Formation is a lakeside sedimentary environment, where dinosaur bones were transported from the flood plain to the lakeside delta by the river within a short distance. Therefore, the burial type of these dinosaur fossil sites may be hypoautochthonous burial.

Based on the existing research, the dinosaur fossil geosite located at
Puan township, in Yunyang County has huge geoheritage values. In terms of scientific value, the discovery of new species of dinosaurs provides material for studying the evolution of dinosaurs. From the view of esocioeconomic value, the geosite increases local visibility, and with the establishment of the National Geopark, the geosite may promote the development of local geological tourism, and bring new resources for economic development.

\section{Acknowledgements}

The authors wish to thank the staff of the 208 Hydroge-ological Engineering Geological Team, especially Haiqian Hu, Zhenglong Zhang, Guangjing Zhang, for their assistance with field work. This study was supported by Project of Dinosaur Fossil Protection and Research of Chongqing Planning and Natural Resources Bureau (KJ-2018035), the National Natural Science Foundation of China (41972118) and the Sixth Funding program for the Development of Young and Middle aged teachers of Chengdu University of Technology (JXGG201719).

\section{References}

A press conference was held in Chongqing on the rescue discovery of dinosaur fossils in Puan township, Yunyang county. 
http://www.scio.gov.cn/xwfbh/gssxwfbh/xwfbh/chongqing/Document/ 1556490/1556490.htm [accessed 20th May 2020]

Barrett, P.M., Butler, R.J., and Knoll, F., 2005, Small-bodied ornithischian dinosaurs from the Middle Jurassic of Sichuan, China. Journal of Vertebrate Paleontology, v. 25, pp. 823-834. doi:org/10.1671/0272-4634(2005) 025[0823:sodftm]2.0.co;2

Benson, R.B.J., 2018, Dinosaur macroevolution and macroecology. Annual Review of Ecology, Evolution, and Systematics, v. 49, pp. 379-408. doi:org/10.1146/annurev-ecolsys-110617-062231

Dai, H., Benson, R., Hu, X.F., Ma, Q.Y., Tan, C., Li, N., Xiao, M., Hu, H.Q., Zhou, Y.X., Wei, Z.Y., Zhang, F., Jiang, S., Li, D.L., Peng, G.Z., Yu, Y.L., and Xu, X., 2020a, A new possible megalosauroid theropod from the Middle Jurassic Xintiangou Formation of Chongqing, People's Republic of China and its implication for early tetanuran evolution. Scientific Reports, v. 10, pp. 1-16. doi:org/10.1038/s41598-01956959-x

Dai, H., Ma, Q.Y., Hu, X.F., Zhou, Y.X., Tan, C., and Li, N., 2020b, A New Dinosaur Fauna is Discovered in Yunyang, Chongqing, China. Acta Geologica Sinica-English Edition, v. 94, pp. 216-217. doi:org/10.1111/ $1755-6724.14516$

Davies, N.S., Shillito, A.P., Slater, B.J., Slater, B.J., Liu, A.G., and Mcmahon, W.J., 2020, Evolutionary synchrony of Earth's biosphere and sedimentary-stratigraphic record. Earth-Science Reviews, v. 201. doi:org/ 10.1016/j.earscirev.2019.102979

Deng, S.H., Lu, Y.S., Zhao, Y., Fan, R., Wang, Y.D., Yang, X.J., Li, X., and Sun, B.N., 2017, The Jurassic palaeoclimate regionalization and evolution of China. Earth Science Frontiers, v. 24, pp. 106-142. doi:org/ 10.13745/j.esf.2017.01.007

Fuertes-Gutiérrez, I., García-Ortiz, E., and Fernández-Martínez, E., 2016, Anthropic threats to geological heritage: characterization and management: a case study in the dinosaur tracksites of La Rioja (Spain). Geoheritage, v. 8, pp. 135-153. doi:org/10.1007/s12371-015-0142-3

Jo, H.R., and Chough, S.K., 2001, Architectural analysis of fluvial sequences in the northwestern part of Kyongsang Basin (Early Cretaceous), SE Korea. Sedimentary Geology, v. 144, pp. 307-334. doi:org/10.1016/ s0037-0738(01)00123-3

Li, N., Dai, H., Tan, C., Hu, X.F., Wei, Z.Y., Lin, Y., Wei, G.B., Li, D.L., Meng, L., Hao, B.Q., You, H.L., and Peng, G.Z., 2019, A neornithischian dinosaur from the Middle Jurassic Xintiangou Formation of Yunyang, Chongqing, China: the earliest record in Asia. Historical Biology, pp. 1-14. doi:org/10.1080/08912963.2019.1679129

Luo, Y.N., and Wang, C.S., 1999, New discovery on dinosaur fossils from Early Jurassic, Sichuan, China. Chinese Science Bulletin,v. 44, pp. 2182-2188. doi: org/10.1007/BF03182705

Novacek, M.J., and Cleland, E.E., 2001, The current biodiversity extinction event: scenarios for mitigation and recovery. Proceedings of the National Academy of Sciences, v. 98, pp. 5466-5470. doi:org/10.1073/ pnas. 091093698

Office of national natural park evaluation commission, national forestry and grassland administration Publication of the results of the second national nature park assessment in 2019.

http://www.forestry.gov.cn/html/main/main_4461/20200119152638963485738/ file/20200119153206012911696.pdf [accessed 20th May 2020]

Smith, R.M.H., 1995, Changing fluvial environments across the PermianTriassic boundary in the Karoo Basin, South Africa and possible causes of tetrapod extinctions. Palaeogeography, Palaeoclimatology, Palaeoecology, v. 117, pp. 81-104. doi:org/10.1016/0031-0182(94)00119-S

Tan, C., Xiao, M., Dai, H., Hu, X.F., Li, N., Ma, Q.Y., Wei, Z.Y., Yu, H.D., Xiong, C., Peng, G.Z., Jiang, S., Ren, X.X., and You, H.L., 2020, A new species of Omeisaurus (Dinosauria: Sauropoda) from the Middle Jurassic of Yunyang, Chongqing, China. Historical Biology, pp. 1-13. doi:org/ 10.1080/08912963.2020.1743286

Wang, Y.D., Fu, B.H., Xie, X.P., Huang, Q.S., Li, K., Li, G., Liu, Z.S., Yu, J.X., Pan, Y.H., Tian, N., and Jiang, Z.K., 2010, The terrestrial Triassic and Jurassic Systems in the Sichuan Basin, China. University of Science and Technology of China Press, Heifei, China.

Xing, L.D., Peng, G.Z., Marty, D., Ye, Y., Klein, H., Li, J.J., Gierliński, G.D., and Shu, C.K., 2013, An unusual trackway of a possibly bipedal archosaur from the Late Triassic of the Sichuan Basin, China. Acta Palaeontologica Polonica, v. 54, pp. 863-871. doi:org/10.4202/app.2012.0087

Xing, L.D., Peng, G.Z., Ye, Y., Lockley, M.G., Klein, H., Persons IV, W.S., Zhang, J.P., Shu, C.K., and Hao, B.Q., 2014, Sauropod and small theropod tracks from the Lower Jurassic Ziliujing Formation of Zigong City, Sichuan, China, with an overview of Triassic-Jurassic dinosaur fossils and footprints of the Sichuan Basin. Ichnos, v. 21, pp. 119-130. doi:org/ 10.1080/10420940.2014.909352

Xing, L.D., Lockley, M.G., Marty, D., Klein, H., Yang, G., Zhang, J.P., Peng, G.Z., Ye, Y., Persons IV, W.S., Yin, X.Y., and Xu, T., 2016, A diverse saurischian (theropod-sauropod) dominated footprint assemblage from the Lower Cretaceous Jiaguan Formation in the Sichuan Basin, southwestern China: a new ornithischian ichnotaxon, pterosaur tracks and an unusual sauropod walking pattern. Cretaceous Research, v. 60, pp. 176-193. doi:org/10.1016/j.cretres.2015.12.005

Xing, L.D., Dai, H., Lockley, M.G., Romilio, A., Klein, H., Li, Z.D., Hu, X.F., Peng, G.Z., Ye, Y., and Persons IV, W.S., 2018, Two new dinosaur tracksites from the Lower Cretaceous Jiaguan Formation of Sichuan Basin, China: specific preservation and ichnotaxonomy. Historical Biology, v. 30, pp. 976-984. doi:org/10.1080/08912963.2017.1326113

Yunyang solicits the master plan of dinosaur Geopark from the whole world. https://www.cqrb.cn/html/cqrb/2018-01/21/003/content_192304.htm [accessed 20th May 2020]

Zhang, H., Cao, C.Q., Liu, X.L., Mu, L., Zheng, Q.F., Liu, F., Xiang, L., Liu, L.J., and Shen, S.Z., 2016, The terrestrial end-Permian mass extinction in South China. Palaeogeography, Palaeoclimatology, Palaeoecology, v. 448, pp. 108-124. doi:org/10.1016/j.palaeo.2015.07.002

Zhang, H.L., Yang, W.G., Zhou, Y.X., Li, D.L., Dai, H., Tan, C., and Yu, H.D., 2020, Geochemical Characteristics and Geological Significance of a Clastic Rock in the Shaximiao Formation of the Dinosaur Fossil Burial Area in Yunyang Chongqing. Mineralogy and Petrology, v. 40, pp. 26-35. doi:10.19719/j.cnki.1001-6872.2020.02.03

Zhou, Y.X., Hu, H.Q., Dai, H., Tan, C., Yang, W.G., and Zhang, H.L., 2020, The discovery of dinosaurs from the Middle Jurassic Xitiangou Formation in Xinjin Township, Yunyang, Chongqing, and its sedimentary environment. Geological Bulletin of China, v. 39, pp. 1527-1537.

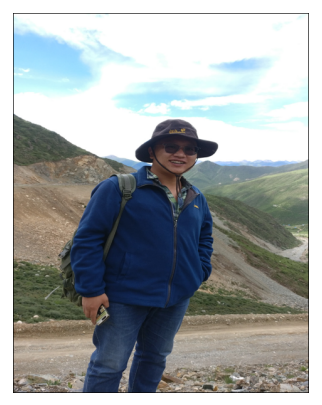

Hongliang Zhang is a phD Candidate of College of Earth Sciences at Chengdu University of Technology. His research has been concerned sedimentary geology, geoheritage and geochemistry. The research focuses on the Qinghai-Tibet Plateau and Sichuan Basin.

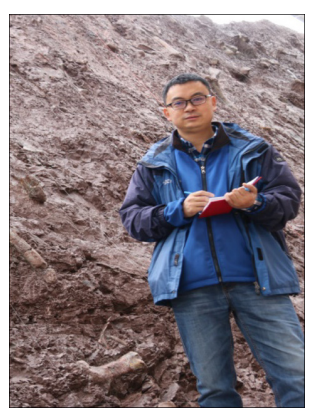

Wenguang Yang is a lecturer of Chengdu University of Technology. His research interests involve paleoclimate and palaeobios. The research focuses on the Qinghai-Tibet Plateau and Sichuan Basin. 


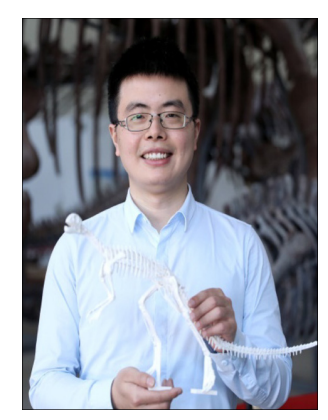

Hui Dai is a doing his postdoctoral research with the world famous palaeontologist Professor Xuxing of the Institute of Vertebrate Paleontology and Paleoanthropology, Chinese Academy of Sciences. He is now the director of Chongqing Geological Heritage Protection and Research Laboratory. He is specialized in the field of palaeontology and palaeoecology. He has published over 15 research papers in international journals.

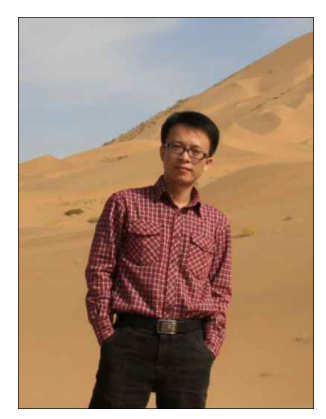

Deliang $\boldsymbol{L} \boldsymbol{i}$ is a phD Candidate of College of Environment and Civil Engineering at Chengdu University of Technology, and also belong to Chongqing Insitute of Geology Survey. His research concerned with Jurassic paleoclimate and palaeoenvironment.

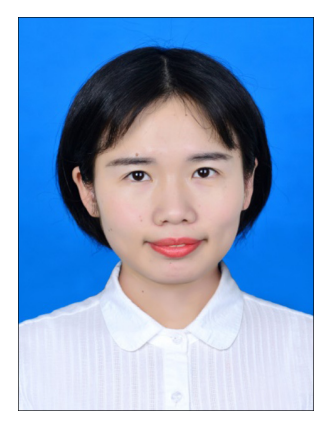

Yuxuan Zhou is a doctoral students of Institute of Sedimentary Geology, Chengdu University of Technology, and also belong to Chongqing Geological Heritage Protection and Research Laboratory. Her research has been concerned with Jurassic paleoclimate and palaeoenvironment.

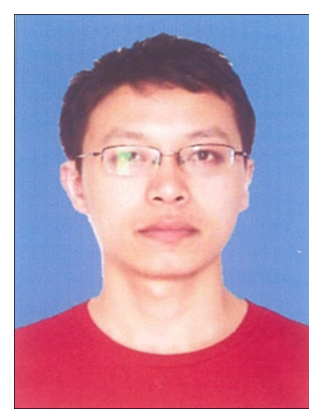

Haidong $\mathbf{Y u}$ is studying his master degree at China University of Geosciences (Beijing), and is a member of the Chongqing Geological Heritage Protection and Research Laboratory. His research interests involve engineering, hydrogeological and environmental geology.

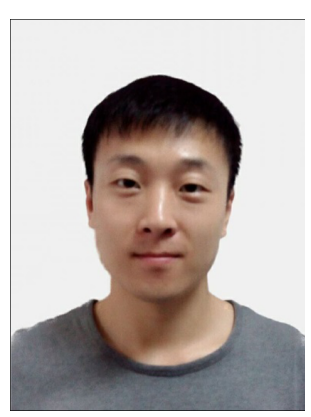

Y $\boldsymbol{u}$ Lin graduated from Hebei University of Geosciences several years ago. He is a member of the Chongqing Geological Heritage Protection and Research Laboratory. He is mainly engaged in basic geology, geological heritage survey, protection and research related work. 